\title{
Altıngözlü Böcekler Neden Antenlerini Kırarlar?
}

\author{
Why Do Golden Eyed Lacewings (Neuroptera: Chrysopidae) Break Their Antennas?
}

\author{
Hakan BOZDOĞAN*
}

Ahi Evran Üniversitesi, Bitkisel ve Hayvansal Üretim Bölümü, Teknik Bilimler MYO Kırşehir, 40100, Türkiye

\author{
• Geliş tarihi / Received: 08.09.2017•Düzeltilerek geliş tarihi / Received in revised form: 10.01.2018 • Kabul tarihi / Accepted: 19.01 .2018
}

\section{Sayın Editör,}

Altıngözlü'ler olarak bilinen ve yine bu isimle literatüre kazandırılan Chrysopidae Familyası üyeleri, (Neuroptera: Chrysopidae) önemli predatör böceklerdir. Deniz seviyesinden başlayarak 2000 metreli yükselti basamaklarına kadar uzanan mikro ya da makro habitatlarda yaşam süren bu gizemli böcekler, aynı zamanda birer biyolojik mücadele ajanıdırlar. Neuroptera familyası üyeleri sadece tarımsal alanlarda değil ormanlık sahalarda, milli parklarda, süs bitkilerinde ve seralık alanlarda da etkinlik göstermekte ve yaşamlarının belirli dönemlerinde parazitoit olan farklı canlı gruplarını barınak ve yaşam alanı olarak kullanmaktadırlar. Chrysopidae Familyası üyelerinde başlıca dokunma ve koku almada görevli ve çoğunlukla filiform morfolojili bir çift anten bulunmaktadır. Chrysopidae'ler, Neuroptera takımının ikinci büyük familyası olmasının yanı sıra, takımın ekonomik olarak da en önemli familyası durumundadır. $\mathrm{Bu}$ familyanın larvaları ve bir kısım erginleri predatör olup, afit, koşnil, yaprak zararlıs1, beyaz sinek, psillit, trips ve diğer yumuşak vücutlu eklembacaklıları avlayarak beslenirler. $\mathrm{Bu}$ nedenle familyanın bazı türleri, çeşitli tarım alanlarında pestisitlerle mücadelede biyolojik mücadele ajanı olarak başarıyla kullanılmaktadırlar. $\mathrm{Bu}$ yönüyle söz konusu takıma ait türlerin doğada korunması biyolojik mücadele için eşsiz önem arz etmektedir (Canard vd., 1984; Mc Ewen vd., 2001; Bozdoğan vd., 2012).

Sürdürmekte olduğumuz çalışmada, 22 farklı habitattan toplanan 437 kırık antenli altın gözlü familyası üyesi böceğin 89 tanesinin anten çiftinden sadece birisinin kırıldığı saptanmıştır. Kırı olan antenlerin 62 tanesinin sol anten, kalan 27 tanesinin ise sağ anten olduğu kaydedilmiştir.
348 tanesinde ise her iki anten çiftinin de (sağ ve sol) kırıldığ 1 gözlenmiștir. 3 farklı böcek yakalama metodu kullanılarak yürütülen bu çalışmada, böceklerin toplanma metotlarından kaynaklı kırılmalar çalışmaya yansıtılmamıştır. Böcekler, saklama kutularına yerleştirilirken anten çiftleri morfolojik gözlemden geçirilmiştir (Şekil 1).

Öte yandan 291 altıngözlü böcek, doğada toplanmadan fotoğraflanmıştır. Elde edilen fotoğraflar incelendiğinde 104 tanesinin (66 sol, 38 sağ) anten çiftlerinden sadece birisinin kırıldığ saptanmıştır. Tüm bu veriler 1şı̆̆ında, yanıt bekleyen sorular şunlardır:

1. Çoğunluğu larval dönemde predatör olan ergin altın gözlülerin acaba neden antenleri kırılır?

2. Anten kırılmasının trofik bir ağ örgüsü ya da mikro habitat ile direkt ilișkisi var mıdır?

3. Anten kırılması türe özgü kalıtım temelli olmayan bir görüngü müdür?

4. Antenler kırılgan yapıda olsa dahi neden sol anten çifti kırılmaya daha yatkındır?

5. Toplanan ya da fotoğraflanan altıngözlü böceklerin neden aynı konukçuda ve yine aynı mikrohabitatda yer alsa dahi anten kırılma düzey ve lokasyonları farklılıklar göstermektedir?

İçerisinde bizim çalışmamızın da yer aldığ 1 ekolojik-morfoloji tabanlı saha çalışmaları, altıngözlü böceklerin anten morfolojisindeki farklılık ve değișimlere ekolojik bir tanı koyma gerekliliği oluştuğunda, sonuca ulaşmak uzun soluklu gözlem ve uğraş gerektirmektedir. O nedenledir ki yukarıda listelenen tüm bu sorulara, çalışmamızdaki tekerrür sayısını çoğaltmak suretiyle yanit aranacak ve elde edilen bulgular bilim dünyası ile paylaşılacaktır.

* Hakan BOZDOĞAN; hakan.bozdogan@ahievran.edu.tr; Tel: (0551) 86775 48; orcid.org/0000-0002-6836-4383 


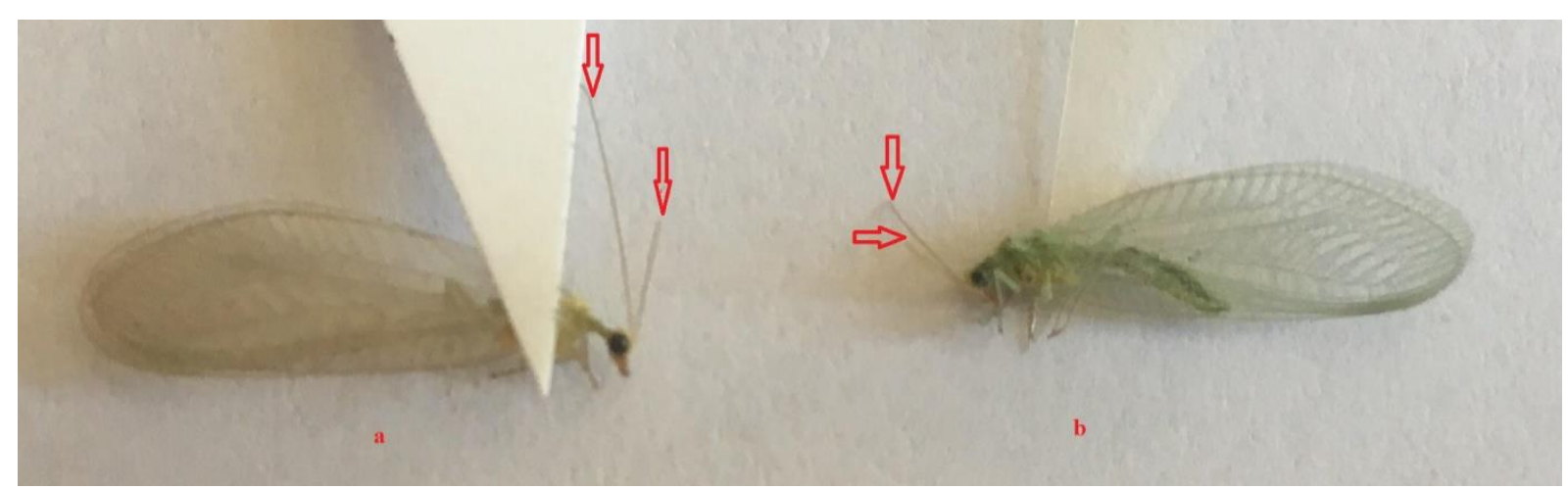

Şekil 1. (a) Kırık antenli Chrysofit türü (Neuroptera:Chrysopidae), kırılmış sol anten, (b) her iki kırılmış anten çifti.

\section{Kaynaklar}

Bozdoğan, H., Bahadıroğlu, C. ve Toroğlu, S., 2012. Altıngözlü Böcekler (Neuroptera: Chrysopidae), Genel Özellikleri ve Biyolojik Mücadelede Önemi., Nevşehir Üniversitesi Fenbilimleri Enstitü Dergisi 1, 51-57.
Canard, M., Séméria, Y. ve New, T.R. (eds.). 1984. Biology of Chrysopidae. Dr W. Junk Publishers, The Hague, 294 pp.

McEwen, P.K., New, T.R. ve Whittington, A.E. (eds.). 2001. Lacewings in the crop environment. Cambridge University Press, Cambridge,546 pp. 